\title{
Choice for the Removal of Bloody Cerebrospinal Fluid in Postcoiling Aneurysmal Subarachnoid Hemorrhage: External Ventricular Drainage or Lumbar Drainage?
}

\author{
Koillenmiş Anevrizmal Subaraknoid Kanamada Kanl Beyin Omurilik \\ Sıvısı Uzaklaştırma Seçeneği: Eksternal Ventriküler Drenaj ya da \\ Lomber Drenaj
}

Chongran $\mathrm{SUN}^{1}$, Hanggen $\mathrm{DU}^{2}$, Lichun $\mathrm{YIN}^{2}$, Min $\mathrm{HE}^{2}$, Yong TIAN ${ }^{2}$, Hongyu $\mathrm{LI}^{2}$

${ }^{1}$ Affiliated $2^{\text {nd }}$ Hospital of Zhejiang University, School of Medicine, Department of Neurosurgery, Hangzhou Zhejiang, China

${ }^{2}$ Affiliated $2^{\text {nd }}$ Hospital of Zhejiang Chinese Medical University, School of Medicine, Department of Neurosurgery, Hangzhou Zhejiang, China

Corresponding Author: Hongyu LI / E-mail: hongyuzju@126.com

\begin{abstract}
AIM: External ventricular drainage (EVD) and lumbar drainage (LD) are the most widely used procedures for continued bloody cerebrospinal fluid drainage. Each has his own advantages and disadvantages. Here, we compared complications and clinical outcomes in patients with World Federation of Neurosurgical Societies (WFNS) grade III aneurysmal subarachnoid hemorrhage (aSAH) who underwent coil placement followed by EVD or LD.

MATERIAL and METHODS: In this prospective, controlled study, all patients with aSAH classified as WFNS grade III who underwent coil placement at our institution were divided randomly into 2 groups: the EVD group and the LD group. The ratios of intracerebral hemorrhage, vasospasm, infection, duration of catheter placement, hydrocephalus, and Glasgow outcome scale (GOS) after 2 months of onset were analyzed between the 2 groups.

RESULTS: A total of 148 patients (mean age 56.8 years) were enrolled in this study. Seventy-six patients were assigned to the EVD group, and 72 patients were assigned to the LD group. The average time interval from stroke onset to surgery was $35.1 \mathrm{~h}$. Compared with the EVD group, the LD group had a lower incidence of intracerebral hemorrhage, slightly higher rates of infection and hydrocephalus, and similar vasospasm and chronic hydrocephalus rates, durations of catheter placement, and GOS scores at 2 months after onset.

CONCLUSION: In order to improve the clinical outcomes of patients with aSAH, we suggest that LD is better than EVD for patients with WFNS grade III aSAH who underwent coil placement.
\end{abstract}

KEYWORDS: Aneurysmal subarachnoid hemorrhage, Bloody cerebrospinal fluid, External ventricular drainage, Lumbar drainage

öz

AMAÇ: Eksternal ventriküler drenaj (EVD) ve lomber drenaj (LD), kanlı serebrospinal sıvının drenajı için en sık kullanılan işlemlerdir. Her birinin kendi avantaj ve dezavantajları vardır. Burada Dünya Nöroşirürji Dernekleri Federasyonu (WFNS) derece III anevrizmal subaraknoid kanaması (aSAK) olan ve sarmal (koil) yerleştirme sonrasında EVD veya LD yapılan hastalarda komplikasyonlar ve klinik sonuçları karşılaştırdık.

YÖNTEM ve GEREÇLER: Bu prospektif, kontrollü çalışmada WFNS derece III olarak sınıflandırılan ve hastanemizde sarmal yerleştirilen tüm hastalar rastgele olarak 2 gruba bölündü: EVD grubu ve LD grubu. Bu iki grup intraserebral kanama, vazospazm, enfeksiyon, kateter yerleştirme süresi, hidrosefali ve başlangıçtan 2 ay sonra Glasgow sonuç ölçeği (GOS) değerleri açısından karşılaştırıldı.

BULGULAR: Çalışmaya toplam 148 hasta (ortalama yaş 56,8 yıl) kaydedildi. EVD grubunda 76 hasta ve LD grubunda 72 hasta vardı. İnmenin başlamasından cerrahiye kadar ortalama süre 35,1 saatti. EVD grubuna göre LD grubunda intraserebral kanama insidansı daha düşüktü, enfeksiyon ve hidrosefali oranı biraz daha yüksekti ve vazospazm ve kronik hidrosefali oranları, kateter yerleştirme süresi ve başlangıçtan 2 ay sonra GOS puanı benzerdi.

SONUÇ: aSAK hastalarında klinik sonuçların düzelmesi açısından, koil yerleştirilmiş WFNS derece III aSAK hastalarında LD'nin EVD'den daha iyi olduğunu düşünüyoruz.

ANAHTAR SÖZCÜKLER: Anevrizmal subaraknoid kanama, Kanlı serebrospinal sıVı, Eksternal ventriküler drenaj, Lumber drenaj 


\section{INTRODUCTION}

Although aneurysmal subarachnoid hemorrhage (aSAH) is a devastating disease with high morbidity and mortality, medical and surgical advances have improved clinical outcomes in patients with aSAH. The exact pathological mechanism of SAH is not well understood, but there is no doubt that the presence of blood in the subarachnoid space plays a very important role in the clinical outcome of SAH(22). The continued bloody cerebrospinal fluid drainage (CCFD) soon after aSAH could decrease the incidence of clinically significant vasospasm and hydrocephalus associated with aSAH, as compared with alternative medical treatments. CCFD can control intracranial pressure and promote the circulation of clear, newly formed cerebrospinal fluid (CSF) and removal of bloody CSF or clots that are thought to contain spasmogens, which induce the delayed development of ischemic symptoms or cerebral infarctions as a result of vasospasm subsequent to aSAH.

Among the CCFD procedures, external ventricular drainage (EVD) and lumbar drainage (LD) are currently the most widely used techniques. One of the earliest uses of EVD was reported by Kusske in 1973, who used EVD to treated aSAH-related hydrocephalus (16). Because of its precision and reliability for monitoring and reducing intracranial pressure (ICP), EVD has become a standard approach in treating SAH-associated hydrocephalus, and immediate EVD placement for ICP monitoring and control is considered the first step to treating patients with aSAH(21). However, LD is another simple and effective way to promote the clearance of blood from the subarachnoid space.

Both EVD and LD are also associated with several procedureassociated complications. The main complications associated with EVD include infection (40\%) (24), misplacement of the intracranial catheter (12.3\%) (23), and intracerebral hemorrhage (5.7\%) (7). The most significant complication of LD is potential downward herniation of the brain; other complications include cerebral subdural hematoma, lumbar epidural hematoma, infection, etc. Some of these complications can be fatal; therefore, analysis of the safety of these methods is essential. However, to the best of our knowledge, an accurate comparison of the removal of bloody CSF in aSAH following treatment with EVD or LD has not been carried out. Therefore, the purpose of this study was to compare the complications and clinical outcomes of EVD and LD in patients with aSAH.

\section{PATIENTS and METHODS}

This prospective, controlled study was approved by our institutional ethics committee. Patients who suffered from spontaneous SAH were admitted to the Affiliated 2nd Hospital of Zhejiang Chinese Medical University and the Affiliated 2nd Hospital of Zhejiang University School of Medicine from June 2003 to June 2013 within $9 \mathrm{~h}$ after onset. Computed tomography (CT) scans were performed emergently without contrast enhancement if patients were systemically stabilized when arrived. All patients with SAH according to CT scans underwent cerebral angiography and coil placement for the ruptured aneurysm less than $24 \mathrm{~h}$ after onset. All patients received lumbar puncture if the patients were Grade III according to the World Federation of Neurological Societies (WFNS) SAH grading scale (28). We generated a sequence for enrolling a patient and allocating treatment using computergenerated randomized numbers for patients whose pressure upon lumbar puncture was $250 \mathrm{mmH}_{2} \mathrm{O}$ or less (at less than 36 $\mathrm{h}$ after onset). Enrolled patients requiring CCFD for treatment of bloody CSF were randomized to the EVD or LD group for catheter insertion (less than $48 \mathrm{~h}$ after onset). Drainage systems are usually kept at approximately the patient's head level, and the volume is individualized for each patient depending on his neurological status. The daily volume of CSF was controlled, ranging from 150 to $200 \mathrm{ml}$ in the first 3 days after catheter insertion and then from 100 to $150 \mathrm{ml}$ in the following days.

\section{Inclusion Criteria}

Criteria for inclusion in this study were (1) spontaneous primary aneurysmal SAH according to CT scan and cerebral angiography; (2) WFNS grading scale is III; (3) age 18-69 y; (4) admittance within $9 \mathrm{~h}$ and received catheter insertion less than $48 \mathrm{~h}$ after onset; (5) informed consent from patients and/ or their legal representative; (6) functional catheter when good CSF drainage was obtained over the duration of the study.

\section{Exclusion Criteria}

The exclusion criteria used to maintain a well-arranged database in this study were (1) contraindicated for catheter insertion; (2) presence of vasospasm, hydrocephalus, or infection before the catheter insertion; (3) intracerebral hemorrhage or cast ventricles; and (4) the aneurysm was not found using cerebral angiography.

\section{Placement of EVD}

The placement of the EVD was performed under sterile conditions in the operating center. We chose ipsilateral ventricle insertion according to the hemorrhaging side (but preferably on the right side) using a ventricular catheter (Codman external drainage system II). The burr-hole was made under local anesthesia, $1 \mathrm{~cm}$ anterior to the coronal suture and $2.5 \mathrm{~cm}$ lateral to the midline. The EVD were placed in the anterior horn of the lateral ventricle and tunneled under the scalp. The distal end of the catheter was inserted about $5-6 \mathrm{~cm}$ until CSF was well obtained. The catheter was then passed subcutaneously, sutured to the skin, and connected to an external drainage system. The intraventricular location of the catheter tip was confirmed by CT scan after insertion.

\section{Placement of $L D$}

The lumbar catheter was placed at bedside using the following steps. The patient was placed in the right lateral position. The skin of the lumbar area was shaved and prepared. An adult spinal needle was inserted into the subarachnoid 
space, usually at the L4-L5 or L3-L4 intervertebral level, and $1 \%$ lidocaine solution was injected from the skin to the interspinous ligament level for local infiltrative anesthesia. After insertion of the needle, a catheter was advanced through the needle into the subarachnoid space, and the needle was removed. The catheter was then fixed to the skin and connected to an external drainage system.

\section{Outcome Assessment}

\section{Intracerebral Hemorrhage}

All patients received daily CT scans after catheter insertion. Consciousness, pupil dilation, blood pressure, and intracerebral hemorrhage were closely monitored and recorded. Patients with intracerebral hemorrhage needing surgical evacuation underwent operation as soon as possible.

\section{Vasospasm}

Daily transcranial Doppler (TCD) ultrasonography examinations were given to all patients in order to record the blood flow velocity. Mean arterial velocities greater than $120 \mathrm{~cm} / \mathrm{s}$ in the middle cerebral arteries were considered indicative of vasospasm (27). All patients underwent cerebral angiography again if vasospasm was suspected. Vasospasm was defined as: (1) the presence of neurological worsening without other identifiable cause, including focal deficit, decline in level of consciousness, or motor paresis; (2) a new low-density area on CT scans associated with cerebral vasospasm; and (3) confirmation of vasospasm on cerebral angiography.

\section{CSF Infection}

Prophylactic systemic antibiotics were given at the time of catheter insertion. A total of $10 \mathrm{~mL}$ CSF from the external drainage system was collected and analyzed by the laboratory every day, and CSF cultures were obtained for measurement of CSF white blood cells. CSF infection was defined as leukocytosis in CSF on the day that the CSF sample was obtained. Antibiotics were modified according to microbiological sensitivities if microbiological pathogens were identified in the CSF.

\section{Duration of Catheter Insertion}

Intracerebral hemorrhage according to the daily CT scan and CSF quality according to laboratory tests were evaluated; criteria for removal of catheters were as follows: (1) CSF cultures and CSF white blood cells were normal; (2) no blood clots in ventricles and no hydrocephalus according to CT scans; (3) tolerance of clipping catheter for more than 24 $h$ and no symptoms of higher ICP; (4) the CSF culture was negative for CSF infection more than 3 consecutive times.

\section{Hydrocephalus}

Hydrocephalus was defined as an excess of cerebrospinal fluid in the ventricular system. The diagnosis of hydrocephalus was based on clinical presentation and neuroimaging examinations. We divided hydrocephalus into 3 stages: acute ( 0 to 3 days after onset), subacute (4 to 13 days after onset), and chronic ( $\geq 14$ days after onset) (31). Hydrocephalus could present with headache, nausea, vomiting, coma, and/or a gradual slowing of intellectual and motor activity, gait ataxia, cognitive disturbance, and urinary incontinence (29). The diagnosis of hydrocephalus by neuroimaging examinations was made according to CT scans, and the width of the third ventricle and the value of the cella media index $(C M I=B / A$, where $A$ is the largest width of the outer layer of the skull and $B$ is the width of the lateral ventricles at the same layer) were calculated. CMI values above 0.25 and third ventricle widths greater than $7 \mathrm{~mm}$ were considered pathological (12).

\section{The Glasgow Outcome Scale(GOS) Score}

All patients were treated according to a standardized rehabilitation scheme comprised of physical therapy, occupational therapy, and speech therapy. The GOS score (13), ranging from 1 to 5, was then used to assess clinical outcomes at 60 days after onset.

\section{Statistical Analysis}

All statistical analyses were performed using SPSS version 17.0 (SPSS Inc, Chicago, IL). A Student t test was used to compare differences for continuous data which are expressed as mean \pm standard deviation (SD). Other clinical categorical variables of the LD and EVD groups were evaluated using a $\mathrm{X}^{2}$-test and Fisher's exact test. A two-tailed $p<0.05$ was considered significant.

\section{RESULTS}

\section{General Characteristics of Patients}

As shown in Table I, a total of 148 patients were enrolled in this study, including 73 men and 75 women (average age, 56.8 years). The average time interval from stroke onset to coiling was $14.0 \mathrm{~h}(p=0.948)$. The average time interval from stroke onset to surgery was $35.1 \mathrm{~h}(p=0.867)$. There were no differences in patient age, gender, aneurysm location, time interval from onset to operation, and pressure of lumbar puncture between the EVD $(n=76)$ and LD $(n=72)$ groups (Figure 1).

\section{Intracerebral Hemorrhage and Vasospasm}

All patients received daily CT scans after catheter insertion. Seven patients in the EVD group suffered an intracerebral hemorrhage, discovered on the second day for 6 patients and the third day for 1 patient. Four patients did not require operation because of small hemorrhages, while 3 patients required surgical evacuation. However, one of these patients died due to rapid deterioration. In the LD group, no patient developed intracerebral hemorrhage; compared to the incidence in the EVD group, this reduced occurrence of intracerebral hemorrhage was statistically significant (7 versus 0 , respectively; $p=0.014$ ) (Table II).

All patients received daily TCD examinations and monitoring of blood flow velocity. All patients underwent cerebral angiography if vasospasm was suspected based on clinical evidence. The rate of vasospasm in the EVD group was $18.42 \%$ 
(14 of 76), while that in the LD group was $18.05 \%$ (13 of 72) according to cerebral angiography. Six patients in the EVD group had low-density areas because of delayed vasospasm on CT scans, while 7 patients in the LD group showed no significant difference in low-density areas $(p=0.954)$. Patients with vasospasm were treated with triple $\mathrm{H}$ (hypertensive, hypervolemic, and hemodilution) therapy and administration of nimodipine (Table II).

\section{CSF Infection and the Duration of Catheter Placement}

All patients received prophylactic systemic antibiotics at the time of catheter placement. According to laboratory tests of the CSF, CSF white blood cell counts were slightly lower in patients with EVD than in patients with LD (29 versus 32, respectively, and positive CSF culture: 11 versus 13 , respectively; $p=0.437$ ). However, this difference was not statistically significant.

Table I: General Characteristics of the Two Groups of Patients

\begin{tabular}{|c|c|c|c|}
\hline & \multicolumn{2}{|c|}{$n$ of patients } & \multirow[b]{2}{*}{$\mathbf{p}$} \\
\hline & EVD $(n=76)$ & LD $(n=72)$ & \\
\hline Age, y (mean \pm SD) & $56.8 \pm 8.9$ & $56.8 \pm 8.5$ & 0.620 \\
\hline \multicolumn{4}{|l|}{ Gender } \\
\hline Female & 38 & 37 & 0.866 \\
\hline Male & 38 & 35 & \\
\hline \multicolumn{4}{|l|}{ Aneurysm location } \\
\hline Anterior circulation & 39 & 35 & 0.742 \\
\hline Posterior circulation & 37 & 37 & \\
\hline \multicolumn{4}{|c|}{ Time from onset to coiling, $h$} \\
\hline mean $\pm S D$ & $13.9 \pm 6.4$ & $14.0 \pm 6.2$ & 0.948 \\
\hline \multicolumn{4}{|c|}{ Time from onset to surgery, $h$} \\
\hline mean $\pm S D$ & $35.1 \pm 7.1$ & $35.1 \pm 7.2$ & 0.867 \\
\hline \multicolumn{4}{|c|}{ Time to catheter removal, $\mathbf{d}$} \\
\hline mean $\pm S D$ & $10.7 \pm 1.88$ & $11.3 \pm 2.11$ & 0.086 \\
\hline
\end{tabular}

d: days, EVD: external ventricular drainage, h: hours, LD: lumbar drainage, SD: standard deviation, y: years.

Table II: Outcomes of the Two Groups of Patients

\begin{tabular}{|c|c|c|c|}
\hline & $\begin{array}{c}n \text { of } \\
\text { EVD }(n=76)\end{array}$ & $\begin{array}{l}\text { patients } \\
\text { LD }(n=72)\end{array}$ & $\mathbf{p}$ \\
\hline $\begin{array}{l}\text { Intracerebral hemorrhage } \\
\text { No } \\
\text { Yes }\end{array}$ & $\begin{array}{r}69 \\
7\end{array}$ & $\begin{array}{r}72 \\
0\end{array}$ & 0.014 \\
\hline $\begin{array}{l}\text { Vasospasm } \\
\text { No } \\
\text { Yes }\end{array}$ & $\begin{array}{l}62 \\
14\end{array}$ & $\begin{array}{l}59 \\
13\end{array}$ & 0.954 \\
\hline $\begin{array}{l}\text { Leukocytosis } \\
\qquad \begin{array}{l}\text { No } \\
\text { Yes }\end{array}\end{array}$ & $\begin{array}{l}47 \\
29\end{array}$ & $\begin{array}{l}40 \\
32\end{array}$ & 0.437 \\
\hline $\begin{array}{l}\text { Hydrocephalus } \\
\text { Acute/Subacute } \\
\text { Chronic }\end{array}$ & $\begin{array}{c}12(73) \\
1 / 1 \\
10\end{array}$ & $\begin{array}{c}18(72) \\
3 / 6 \\
9\end{array}$ & $\begin{array}{l}0.203 \\
0.031 \\
0.831\end{array}$ \\
\hline $\begin{array}{l}\text { Received VPS } \\
\text { 60-day GOS score } \\
\text { mean } \pm \text { SD } \\
\leq 2(\mathrm{n}[\%])\end{array}$ & $\begin{array}{l}11 \\
4.0 \pm 0.79 \\
\quad 4\end{array}$ & $\begin{array}{c}15 \\
4.2 \pm 0.83 \\
3\end{array}$ & $\begin{array}{l}0.304 \\
0.291 \\
1.000\end{array}$ \\
\hline
\end{tabular}

EVD: external ventricular drainage, LD: lumbar drainage, SD: standard deviation. 
As detailed in the above criteria for catheter removal, patients were required to tolerate catheter clipping for at least $24 \mathrm{~h}$ and have negative CSF cultures before catheters removed. We observed no significant differences in the duration of catheter insertion between EVD and LD groups (10.7 \pm 1.88 versus $11.3 \pm 2.11$ days, respectively; $p=0.086)$. In addition, 2 patients underwent operation, 1 in the EVD group died because of intracerebral hemorrhage, and 3 in the LD group received EVD because of acute hydrocephalus (these patients were excluded) (Figure 2).

\section{Hydrocephalus and GOS Score}

The diagnosis of hydrocephalus was based on clinical presentation and neuroimaging examinations. As shown in Table II, the number of patients with acute and subacute hydrocephalus in the EVD group was significantly lower than in the LD group (2 versus 9, respectively; $p=0.031$ ). However, there no significant difference was observed in the number of patients with chronic hydrocephalus between the EVD and LD groups (10 versus 9 , respectively; $p=0.831$ ). All patients who suffered subacute and chronic hydrocephalus after catheters removed received ventriculoperitoneal shunt (VPS)(11 in EVD versus 15 in LD, respectively; $p=0.304$ ).

GOS scores were assessed in all patients at 60 days after stroke. There were no significant differences in GOS scores between the EVD and LD groups ( $4.0 \pm 0.79$ versus $4.2 \pm 0.83$, respectively; $p=0.291$ ) (Table II).

\section{DISCUSSION}

SAH accounts for only $5 \%$ of strokes, while aneurysm is the cause in $85 \%$ percent of cases(32). Despite advances in observation and treatment of $\mathrm{SAH}, 5 \%-11 \%$ of patients continue to suffer chronic disability as a result of SAH (25).

\section{Early Brain Injury (EBI) Associated with aSAH}

The physiological and cellular events of EBI make significant contributions to patient outcomes. EBI is the result of physiological abnormalities, such as increased intracranial pressure, decreased cerebral blood flow, and global cerebral ischemia, which result in blood brain barrier dysfunction, inflammation, and oxidative cascades leading to neuronal cell death. EBI rather than vasospasm might be responsible for morbidity and mortality within 24-72 h after SAH (26). Researchers should continue to investigate the importance of $\mathrm{EBI}$ and its relevance to patient survival and long-term functional outcomes (3).

\section{Vasospasm Associated with aSAH}

While many experimental and clinical studies have been conducted in the field of aSAH research, the exact pathogenesis of cerebral vasospasm associated with aSAH remains unclear. However, vasospasm is still a leading cause of morbidity and mortality in patients with aSAH and may occur 3-14 days following onset of aSAH. The damage induced by cerebral vasospasm is very extensive. In a rabbit model of experimental SAH, Adem et al. (2) found that vasospasm of choroidal arteries may worsen prognosis. Additionally, the variability of blood pressure observed in SAH suggests that vasospasms-induced petrosal ganglion ischemia may promote the development of hypertension (19).

Many studies have provided evidence that oxidative stress plays a significant role in aSAH.. According to a study conducted by Kao et al (14), estrogen receptor alpha (ERa) is involved in $17 \mathrm{~b}$-estradiol (E2)-mediated prevention of $\mathrm{SAH}$-induced apoptosis. E2 treatment may reverse apoptosis by increasing phosphorylated Akt and ERa protein expression in the dentate gyrus via an ERa-dependent pathway. Additionally,

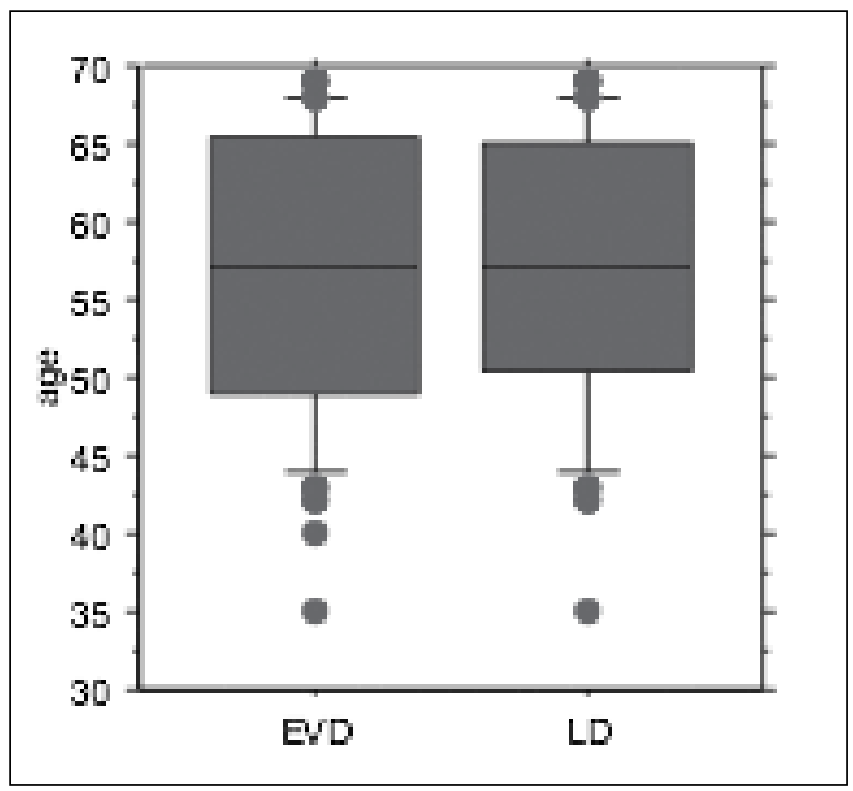

Figure 1: There were no differences in patient age between two groups $(p=0.62)$.

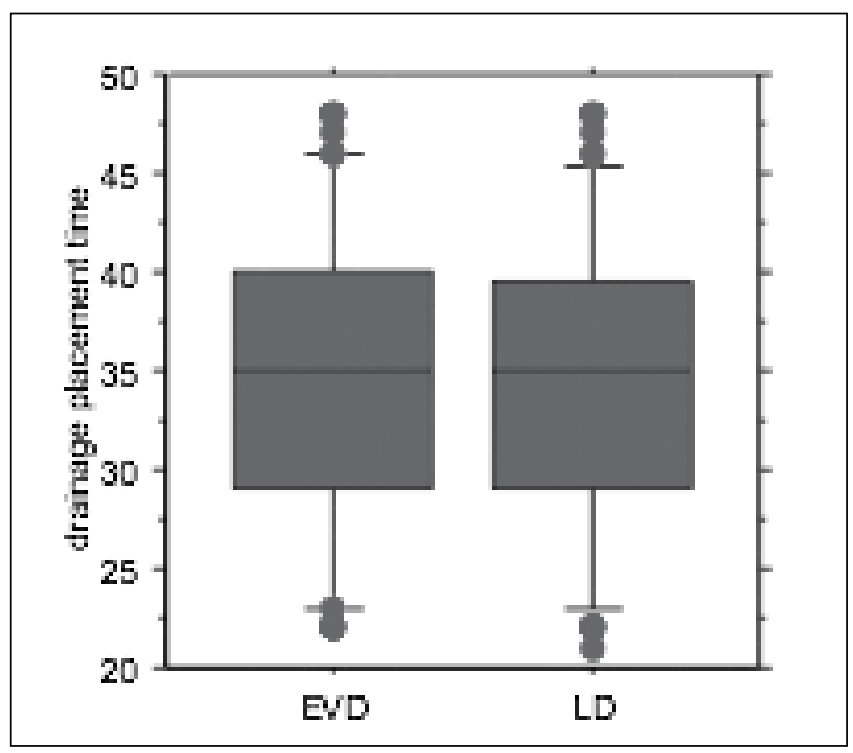

Figure 2: There were no significant differences on the duration of catheter insertion between 73 patients in EVD group and 69 in LD group $(10.7 \pm 1.88 \mathrm{~d}$ versus $11.3 \pm 2.11 \mathrm{~d}, \mathrm{p}=0.086)$. 
alpha lipoic acid (ALA), a strong dithiol antioxidant, may act to prevent cerebral vasospasm after SAH due to its strong antioxidant, antivasospastic, and anti-apoptotic properties (10).

\section{Hydrocephalus Associated with aSAH}

Hydrocephalus, another very common complication in aSAH, was first described by Bagley in 1928 and is defined as an excess of CSF in the ventricular system (4). About $7 \%$ to $37 \%$ of patients develop hydrocephalus after aSAH, and the development of acute hydrocephalus after SAH adversely affects long-term clinical outcome (8). The extent of ventricular dilatation after SAH is a strong risk factor for development of poor functional outcomes in the year following the event (9). The chronic normal-pressure hydrocephalus (cNPH) $(\geq 14 d$ after onset), which was first described by Adams Hakim in 1965 (1) and the most frequent in adults (15), remains a difficulty in diagnose and therapy. Early diagnosis and VPS placement may improve functional outcomes or prevent further functional deterioration (6).

Although many studies have been conducted and clinical outcomes are much improved, the removal of bloody CSF in the subarachnoid space and cisterns is clearly a key aspect to consider during the treatment of vasospasm and hydrocephalus associated with aSAH. Still, EVD and LD are the most widely used methods for continued bloody CSF drainage.

\section{EVD in aSAH}

There are still many controversies surrounding the indications for EVD placement. Some authors monitor and treat only those who demonstrate clinical or radiologic deterioration, while others recommend routine EVD placement in all patients (5). Ventriculomegaly in the setting of GCS $\leq 12$, Hunt-Hess grade $\geq 2$, or inability to follow commands has been used as an indicator for strong consideration of EVD placement(18). However, no conclusive data has determined the impact of EVD placement location on the complication rates and outcomes in patients with aSAH (20). While some place EVDs only in the operating room, others routinely perform the procedure at the bedside (11). In our study, we recommended routine EVD placement in all patients, and placed EVDs only in the operating room. We believe that the operating room provides a more controlled and sterile environment, thereby decreasing the risk of infection.

In our study, we chose ipsilateral ventricle insertion on the primary side of hemorrhage (mostly the right side). However, few studies have investigated the optimal side of the lateral ventricles for EVD placement in patients with aSAH. Wang et al (33) provided a careful comparison between ipsilateral and contralateral EVD in patients with intraventricular hemorrhage and showed that the initial ICP and ICP values in the first 3 days were significantly higher in the ipsilateral group than those in contralateral group; however, no significant differences in mortality rates or functional outcomes were observed at 30 days after stroke between the 2 groups.

\section{LD in aSAH}

Compared with EVD group, the LD group had lower intracerebral hemorrhage, but similar rates of vasospasm and chronic hydrocephalus, durations of catheter placement, and GOS scores at 2 months after onset. There are other advantages of LD. According to Tuettenberg et al (30), the ICP was likely to have been lowered by the volume of CSF drained through the lumbar cistern. They drained 5-20 mL of CSF through an LD and reduced the ICP by half in patients with aSAH. Additional benefits observed included improvements in regional cerebral blood flow and brain tissue oxygen. Removal of the subarachnoid clot through an LD allows removal of spasmogens in the CSF from the spinal cistern within the first few days. Indeed, the percentage of patients rated as having a favorable outcome was significantly higher in the LD group than in the EVD group (36).

Although it is standard practice to give antibiotics prophylactically, and many devices have been developed and tested for this purpose over the past few years, catheter-associated infection poses a great challenge to clinical outcomes (17). Compared to EVD, LD was found to be associated with a slightly higher risk of infection (29 versus 32, respectively; $p=0.437$ ), but no significant difference was observed. This may have been due to the higher risk of contamination associated with the internal position of the LD compared to the external position of the EVD.

Complications with LDs are well recognized, but not common. The most significant complication is potential downward herniation of the brain. Wang et al. (34) insisted that cerebral herniation induced by continuous LD is mostly reversible if identified early and treated right away. Patients with impaired consciousness or large skull defects may be at high risk of developing cerebral herniation after LD and thus require more attention. Other complications include lumbar epidural hematoma with paraplegia, lumbar epidural abscess, cerebral subdural hematoma, meningitis, and retained fragments of catheters related to catheter breakage, etc.

In our study, all patients with ruptured aneurysms underwent coil placement before catheter insertion, and all 7 patients of intracerebral hemorrhage after catheters placement caused by puncture but no re-rupture of aneurysm. One patient died because of intracerebral hemorrhage. The risk of intracerebral hemorrhage in the EVD group was higher than that in the LD group in our study (7 versus 0 , respectively; $p$ $=0.014$ ). Compared with EVD, LD may allow for gradual ICP lowering and insignificant shifts in ICP dynamics, conferring the most benefit to patients. Despite this existing controversy, it is clear that early surgical or endovascular intervention could minimize the risk of rebleeding associated with EVD placement and allow for more aggressive management of ICP, which could subsequently minimize the chance of an ischemic complication (32).

Patients with higher-grade SAH (i.e., WFNS grade IV-V) are more likely to have higher blood loads and ICPs and are more 
likely to have intracerebral and extensive intraventricular hemorrhage, which raises safety issues (36). Although results cannot be extrapolated outside of the study cohort, there is no reason to suggest that poor-grade patients with aSAH would not benefit from LD. Further studies are needed to investigate this hypothesis (35).

Our study had several limitations due to the study design. First, a few neurosurgeons may choose EVD and LD for drainage of bloody CSF. Second, no pediatric patients were included in the study. Third, other risk factors related to patients' outcomes, such as the precise volume CSF of drained, were not analyzed, and patients with poor grade $\mathrm{SAH}$ were not enrolled in this study. Fourth, the study included only a small number of patients, which may have weakened the statistical power of the study. Therefore, further studies with larger sample sizes are necessary to confirm these findings.

\section{CONCLUSION}

We developed a simple, accurate, comprehensive comparison of clinical outcomes in patients who had EVD or LD following coil placement for WFNS grade III aSAH. Our study showed that compared to patients having EVD, patients having LD exhibited reduced intracerebral hemorrhage, slightly higher infection and hydrocephalus in the acute/subacute period, and similar vasospasm, chronic hydrocephalus rates, durations of catheter placement, and GOS scores at 2 months after onset. In order to improve the clinical outcomes of patients with aSAH, we suggest that LD may be better than EVD for patients with WFNS grade III aSAH.

\section{ACKNOWLEDGMENT}

We would like to thank the patients for agreeing to participate in this study. We are grateful to Yong-lu Chen and Li Chen for technical help in this study. This study was partly supported by National Natural Science Foundation of China (grant 81202308).

\section{REFERENCES}

1. Adams RD, Fisher CM, Hakim S, Ojemann RG, Sweet WH: Symptomatic occult hydrocephalus with "normal" cerebrospinal fluid pressure: A treatable syndrome. $\mathrm{N}$ Engl J Med 273:117-126,1965

2. Adem $Y$, Mehmet DA, Ayhan K, Ahmet MM, Sare A, Yunus A, Muhammet C, Nesrin G: The effect of choroidal artery vasospasm on choroid plexus injury in subarachnoid hemorrhage: Experimental study. Turk Neurosurg 21:477482,2011

3. Ayer R, Zhang J: Connecting the early brain injury of aneurysmal subarachnoid hemorrhage to clinical practice. Turk Neurosurg 20:159-166,2010

4. Bagley CJ: Blood in the cerebrospinal fluid: Resultant functional and organic alterations in the central nervous system. Arch Surg 17:18-38,1928
5. Bederson JB, Connolly EJ, Batjer HH, Dacey RG, Dion JE, Diringer MN, Duldner JE, Harbaugh RE, Patel AB, Rosenwasser $\mathrm{RH}$ : Guidelines for the management of aneurysmal subarachnoid hemorrhage: A statement for healthcare professionals from a special writing group of the Stroke Council, American Heart Association. Stroke 40:994-1025,2009

6. Chen Z, Song WQ, Du JB, Li GQ, Yang YH, Ling F: Rehabilitation of patients with chronic normal-pressure hydrocephalus after aneurysmal subarachnoid hemorrhage benefits from ventriculoperitoneal shunt. Top Stroke Rehabil 16:330-338,2009

7. Daniel D, Binz L, Gerard T, Friedman JA: Hemorrhagic complications of ventriculostomy placement: A meta-analysis. Neurocrit Care 10:253-256, 2009

8. Dorai Z, Hynan LS, Kopitnik TA, Samson D: Factors related to hydrocephalus after aneurysmal subarachnoid hemorrhage. Neurosurg 52:769-771,2003

9. Dupont $S$, Rabinstein AA: Extent of acute hydrocephalus after subarachnoid hemorrhage as a risk factor for poor functional outcome. Neurol Res 35: 107-110,2013

10. Erdi MF, Guney O, Kiyici A, Esen H: The effects of alpha lipoic acid on cerebral vasospasm following experimental subarachnoid hemorrhage in the rabbit. Turk Neurosurg 21: 527-533,2011

11. Gardner PA, Engh J, Atteberry D, Moossy JJ: Hemorrhage rates after external ventricular drain placement. J Neurosurg 110:1021-1025,2009

12. Jartti $P$, Karttunen A, Isokangas JM, Jartti A, Koskelainen T, Tervonen O: Chronic hydrocephalus after neurosurgical and endovascular treatment of ruptured intracranial aneurysms. Acta Radiol 49:680-686,2008

13. Jennett $B$, Bond $M$ : Assessment of outcome after severe brain damage: A practical scale. Lancet 1:480-484,1975

14. Kao CH, Chang CZ, Su YF, Tsai YJ, Chang KP, Lin KT, Hwang SL, Lin CL: $17 \beta$-estradiol attenuates secondary injury through activation of Akt signaling via estrogen receptor alpha in rat brain following subarachnoid hemorrhage. J Surg Res 183: e23-e30,2013

15. Kondziella D, Sonnewald U, Tullberg M, Wikkelso C: Brain metabolism in adult chronic hydrocephalus. J Neurochem 106:1515-1524,2008

16. Kusske JA, Turner PT, Ojemann GA, Harris AB: Ventriculostomy for the treatment of acute hydrocephalus following subarachnoid hemorrhage. J Neurosurg 38:591-595, 1973

17. Lackner P, Beer R, Broessner G, Helbok R, Galinao K, Pleifer C, Pfausler B, Brenneis C, Huck C, Engelhardt K, Obwegeser AA, Schmutzhard E: Efficacy of silver nanoparticles-impregnated external ventricular drain catheters in patients with acute occlusive hydrocephalus. Neurocrit Care 8:360-365,2008

18. Mack WJ, King RG, Ducruet AF, Kreiter K, Mocco J, Maghoub A, Mayer S, Connolly ES: Intracranial pressure following aneurysmal subarachnoid hemorrhage: Monitoring practices and outcome data. Neurosurg Focus 14:1-5,2003 
19. Musluman AM, Aydin MD, Yilmaz A, Cansever T, Kanat A, Gundogdu C, Cakir Z, Emet M, Gursan N, Aydin N, Unal B: The effect of degenerated neuron density of petrosal ganglion on the development of blood pressure variabilities after subarachnoid hemorrhage in a rabbit model: an experimental study. Turk Neurosurg 21:559-566,2011

20. Paul G, Brina Y, Hwang GA, Kellner CP, Kellner MA, Connolly ES: External ventricular drainage following aneurysmal subarachnoid haemorrhage. Bri J Neurosurg 24: 625-632,2010

21. Ransom ER, Mocco J, Komotar RJ, Sahni D, Chang J, Hahn DK, Kim GH, Schmidt M, Sciacca RR, Mayer SA, Connolly ES: External ventricular drainage response in poor grade aneurysmal subarachnoid hemorrhage: Effect on preoperative grading and prognosis. Neurocrit Care 6:174-180, 2007

22. Reilly C, Amidei C, Tolentino J, Jahromi BS, Macdonald RL: Clot volume and clearance rate as independent predictors of vasospasm after aneurysmal subarachnoid hemorrhage. J Neurosurg 101:255-261, 2004

23. Saladino A, Bradley W, Eelco FME,Lanzino G: Malplacement of ventricular catheters by neurosurgeons. Neurocrit Care 10:248-252, 2009

24. Scheithauer S, Burgel U, Ryang YM, Haase G, Schiefer J, Koch $\mathrm{S}$, Hafner $\mathrm{H}$, Lemmen $\mathrm{S}$ : Prospective surveillance of drainassociated meningitis/ventriculitis in a neurosurgery and a neurologic intensive care unit. J Neurol Neurosurg Psychiatry 80:1381-1385,2009

25. Seiler RW, Binggeli R: Is cerebral vasospasm still a clinical problem? Acta Neurochir Suppl 77:1-4,2001

26. Simge Y, Yusuf BT, Julian C, Ihsan S: Early brain injury following aneurysmal subarachnoid hemorrhage: Emphasis on cellular apoptosis. Turk Neurosurg 22:529-533,2012

27. Sloan MA, Haley JE, Kassell NF, Henry ML, Stewart SR, Beskin RR, Sevilla EA, Tomer JC: Sensitivity and specificity of transcranial Doppler ultrasonography in the diagnosis of vasospasm following subarachnoid hemorrhage. Neurology 39:1514-1601,1989
28. Teasdale GM, Drake CG, Hunt W, Kassell N, Sano K, Pertuiset B: A universal subarachnoid hemorrhage scale: Report of a committee of the World Federation of Neurosurgical Societies. J Neurol Neurosurg Psychiatry 51:1457-1463,1988

29. Tisell $M$, Hoglund $M$, Wikkelso $C$ : National and regional incidence of surgery for adult hydrocephalus in Sweden. Acta Neurol Scand 112:72-75,2005

30. Tuettenberg J, Czabanka M, Horn P, Woitzik J, Barth M, Thome C, Vaikoczy P, Schmiedek P, Muench E: Clinical evaluation of the safety and efficacy of lumbar cerebrospinal fluid drainage for the treatment of refractory increased intracranial pressure. J Neurosurg 110:1200-1208,2009

31. Vale FL, Bradley EL, Fisher WS III: The relationship of subarachnoid hemorrhage and the need for postoperative shunting. J Neurosurg 86:462-466,1997

32. Van Gijn J, Kerr RS, Rinkel GJE: Subarachnoid haemorrhage. Lancet 369:306-318,2007

33. Wang K, Du HG, Yin LC, He M, Hao BL, Chen L: Which side of lateral ventricles to choose during external ventricular drainage in patients with intraventricular hemorrhage: Ipsilateral or contralateral? J Surg Res 183:720-725,2013

34. Wang K, Liu ZY, Chen XZ, Lou MQ, Yin J: Clinical characteristics and outcomes of patients with cerebral herniation during continuous lumbar drainage. Turk Neurosurg 23: 653-657,2013

35. Yahia Z AT, Deepti B, Richard GF, Hall G, Goddard AJP, Quinn $A C$, Ross SA: Lumbar drainage of cerebrospinal fluid after aneurysmal subarachnoid hemorrhage: A prospective, randomized, controlled trial (LUMAS). Stroke 43:677-682,2012

36. Yoshihiko M, Satoshi S, Hiroshi Y, Hideyuki I, Mizuya S, Fumiaki O, Hirokazu S, Katsuhiko U, Yuichi S, Shohei K, Yukari H, Tomoro S, Kaori N, Hiroyasu K, Sadahiro N, Michiyasu S: Comparison of lumbar drainage and external ventricular drainage for clearance of subarachnoid clots after Guglielmi detachable coil embolization for aneurysmal subarachnoid hemorrhage. Neurol Neurosurg 115:965-970,2013 